\title{
IKZF2 Gene
}

National Cancer Institute

\section{Source}

National Cancer Institute. IKZF2 Gene. NCI Thesaurus. Code C80026.

This gene is involved in both transcription and lymphocyte development. 